Research.

\title{
Differences in individual demographic factors in the public accountant's ethical judgment process
}

\author{
Yuli Anwar \\ Department of Accounting, Economic College of Binaniaga, Bogor, Indonesia \\ juli_anwar@yahoo.com (Y. Anwar)
}

Received: February 11, 2019; Accepted: April 25, 2019; Published: June 30, 2019.

To cite this article: Anwar, Y. (2019). Differences in individual demographic factors in the process accountant's ethical judgment process. The Accounting Journal of BINANIAGA. 4 (1): 01-14. doi:

Abstract. This research aims to examine the differences in individual demographic factors in the public accountant's ethical judgment process in Indonesia. Data collected using purposive sampling and total of the samples is 301 respondents of accountants in Indonesia. The Result, revealed that: (a) there is no difference in ethical judgment of public accountants based on age, gender, experience, and status and (b) there are differences in ethical judgment of public accountants based on education level. These results revealed that public accountants in carrying out their duties and obligations as external auditors in private and government companies have no difference in terms of ethical judgment when deciding matters related to the audit they are undergoing due to age, gender, experience, and status. The difference in ethical judgment of public accountants in carrying out their duties and obligations when deciding matters related to deciding audit work will be different between public accountants who have S3 and S2 education with S1 and D3. Ethical judgment carried out by those with S3 and S2 education will be more careful in deciding because if it is wrong it will have an impact on the future.

Keywords: Demographic Factors, Public Accountant, Ethical Judgment.

\section{Background}

Accounting reporting deviations made intentionally by business people by involving accountants in large, medium and small scale companies that are still occurring to date are very concerning (in 2017 Ernst \& Young's/EY partner public accounting firm in Indonesia KAP Purwantono, Suherman \& Surja agreed to pay a fine of US \$ 1 million/around Rp. 13.3 billion to US regulators, as a result of being convicted of failing to audit their clients' financial statements, Deloitte \& Touche LLP through its business unit in Brazil agreed to pay fines to PCAOB for US $\$ 8$ million because it was convicted of covering up false audit reports, in 2014 PwC auditors were considered to have failed in carrying out their work as auditors in auditing the financial statements of Tesco companies and several Indonesian public accountants during 2017 and 2018 were sanctioned by the Finance Minister of the Republic of Indonesia, public accountants (1) Achmad Rodi The Kartamulja was revoked as a public accountant (2) Soetjipto Wirjosoemarto, Hizbullah Husein, Arthawan Santika, and Meilina Pangaribuan were permitted as public accountants for 12 months). Accounting violations are carried out from simple to structured, systematic and massive violations. As a result of various violations, financial report users such as investors, creditors, and the government again questioned how the existence / existence of public accountants who are independent parties in assessing the fairness of financial statements.

Yuli Anwar. Differences in individual demographic factors in the process accountant's ethical judgment process 
In Indonesia, the issue of accountant ethics develops along with the occurrence of several ethical violations, both carried out by the Office of public accountants, public accountants, internal accountants and government accountants. Behaviors that are not in accordance with the code of ethics of the accounting profession should not be allowed to continue to occur because they will damage the public trust in the accounting profession.

Barrainkua and Pike (2017) state that more studies are needed to study and analyze how professional values influence behavioral outcomes (such as the auditors' ethical decision making, turnover intention, or dysfunctional behavior). Ostermark (2012), suggests further research to test each dimension of social pressures, locus of control, and professional commitment to the auditors' behavior and judgment by using a larger sample (>70). Jones (2002), has conducted a survey of honesty and professional ethics with the results that $35 \%$ of public accountants are respected because they have high honesty, $62 \%$ of the people consider accounting ethics to be very low on average. The results of $35 \%$ of research conducted by Poll only raised a little rating from what he did in February 2002 by $32 \%$, but it was still far below the results of research conducted in November 2001 of $41 \%$. This decline in public perception of honesty and professional ethics is the impact of the unethical behavior of a small number of accountants and public accounting firms.

Accountants play a very important role in monitoring and maintaining important information and are obliged to act as accountants who are professionally responsible (Satava, Caldwell and Richards, 2006). Hunt and Vitell, 2006 emphasize that it is very important for public accountants to recognize and understand contextual factors such as professional norms that have a major impact on business.

The ethical judgment of public accountants plays an important role in applying accounting skills. The ethical dilemma that is always faced by public accountants, namely when faced with doubtful ethical testing situations on the impact of moral standards and their own ethical beliefs, which consequently influences their judgment and behavior (Jones, 1991). Nur et al. (2014) said that nowadays, the more they follow the professional code of ethics, have good expertise, and experience of an accountant, the more appropriate opinions will be given and the audit situation does not have a significant relationship with the accuracy of giving opinions. Booth and Schulz (2004), state that the reinforcement of ethical codes has a significant impact on manager behavior.

It is known that to date some violations regarding ethics still occur both those carried out by public accountants, internal accountants, government accountants, and public accounting firms, so this study is intended to fill the gap by examining the differences in individual factors of public accountant demographics in ethical processes judgment. This research will focus on reviewing and empirically proving individual differences in the demographics of public accountants throughout Indonesia.

The motivation of this research is to know, test, analyze, and prove empirically the broad impact of violations of professional ethics conducted by public accountants making the issue of ethical considerations an interesting issue to be discussed, reviewed, analyzed, and empirically proven regarding individual factors demographics of public accountant in the process of ethical judgment in giving opinions.

Once the importance of ethical judgment for a public accountant makes the issue interesting to study. Brooks and Dunn (2015: 137), states that most accountants assume that mastery of accounting and / or audit techniques is very important thing sine qua non (which is inseparable) from the accounting profession. But there are few financial scandals caused by methodological errors in the application of techniques, most of the financial scandals are caused by misjudgment about the application of appropriate techniques or related disclosures. Some errors in the assessment come from a misinterpretation of the problem resulting from the complexity of the problem, the rest is a result of lack of attention to matters of an ethical nature, such as honesty, integrity, objectivity, caring, confidentiality, and commitment to prioritizing the interests of others above interests personal.

Yuli Anwar. Differences in individual demographic factors in the process accountant's ethical judgment process 


\section{Review of Literature and Hypothesis}

\section{Ethical Theory}

Brooks and Dunn (2014: 161) state that the main ethical theories that are useful in resolving ethical dilemmas are teleology of utilitarianism. Teleology comes from the Greek word telos, which means the end, consequence, result; so, teleological theories that study behavioral ethics in terms of causes or consequences of ethical decisions. Teleology is suitable for many results-oriented businesses because it focuses on the impact of decision making. Teleology evaluates decisions as good or bad, acceptable or unacceptable, in terms of the consequences of that decision. In education, Anwar (2016), revealed that ability of lecturer to transfer the knowledge to their students not be separated from any aspects that related with his/her emotional quality. Inner emotional quality of each lecturer as good as can control, manage, and give motivation for themselves in teaching learning process. Meanwhile, personal value is shown as a as a framework for permanent perception of the relativity that shape and influence the behavior of individuals in general.

The ethicality of the decision maker and the decision has been determined based on the non-ethical comparative value of an action or consequence. If the decision brings positive results, such as helping an individual to achieve selfrealization, then the decision is said to be ethically correct. Other positive non-ethical results include happiness, pleasure, health, beauty, and knowledge, while negative non-ethical results include unhappiness, misery, illness, ugliness, and ignorance. In other words, the assessment of right and wrong, or ethical truth is only based on whether good or bad things happen or not.

Griffin and Pustay (2015: 115) define ethics as individual personal beliefs about whether a decision, behavior, or action is something that is right or wrong. Therefore, what constitutes ethical behavior varies from one person to another. An individual's ethics is determined by a combination of several factors. People begin to form ethical frameworks in childhood in response to their perceptions of the behavior of parents or other adults associated with them.

According to Brooks and Dunn (2014: 152), ethics is a branch of philosophy that investigates normative judgments about whether this behavior is right or what should be done. Ethical needs arise from the desire to avoid problems in the real world. Ethics does not refer to problems about what you must or do not believe; such things are listed in religious codes. Instead, ethics is related to the principles that guide human behavior. Ethics is learning about norms and values that are related to wrong and right, good and bad, as we must do and what actions we must avoid. Regarding ethics, Lawrence and Weber (2014: 69) suggest that:

Ethics is a conception of right and wrong conduct. It tells us whether the behavior is moral and deals with fundamental human relationships how we think and behave to others and how we want them to think and behave toward us. Ethical principles are guides to moral behavior. For example, most people lying, stealing, deceiving, and harmonizing others are considered to be unethical and immoral. Honesty, promises, helping others, and respecting rights are considered to be ethically and morally. Desirable behavior. Such basic rules of conduct are essential for the preservation and continuation of organized life everywhere.

It can be said that ethics describes an embodiment of norms and behavior that can help humans to act freely and accountable. This has a special meaning because every action taken by humans is the result of the decisions taken themselves accompanied by the availability of various opportunities to account for their value. According to Bertens (2015: 6-7), explain various definitions of ethics, as follows:

a. Ethics can be used in the sense of values and morals that are a guideline for a person or group in regulating their behavior. For example, if people talk about the

Yuli Anwar. Differences in individual demographic factors in the process accountant's ethical judgment process 
ethics of Indian tribes, Buddhist ethics, ethics of Protestant religion (Max Weber, The Protestant Ethic and Spirit of Capitalism), Islamic ethics, Conghucu ethics. This meaning can also be formulated as a value system. It may be noted again, the value system can function in individual human life and at the social level.

b. Ethics can be used in terms of the norms of behavior, procedures for doing, systems of behavior, manners. More explicitly is the code of ethics. For example, a journalistic code of ethics, a code of ethics for civil servants, a code of ethics for teachers, a code of ethics for preachers. In this case, science is not meant but the meaning of procedure. In brief, this meaning can be formulated as a system of rules or regulations.

c. Ethics can be used in the sense of good-bad behavior, may not be allowed, like it or not, happy to be unhappy. Such ethics can be recognized if the ethical behavior of the principles and values contained in the general measure is bad, accepted by the community in a place, becomes a joint agreement and is carried out together.

\section{Deontology Ethics}

Deontology evaluates your physical ethics based on the motivation of the decision maker, and according to the principle of deontology, action can be justified ethically even if it does not generate a net profit for the good of evil for decision makers or for society as a whole. This makes it a complement to utilitarianism because actions that fulfill both theories can be said to have an ethical opportunity.

Immanuel Khan (1964), giving a clear articulation of this theory is that the only good without exception is only good faith, the intention to follow what determines the reason without regard to its consequences for oneself. He also argued that all moral concepts come from reasons not from experience. Goodness will manifest itself when acting for the sake of duty, where the task implies recognition and obedience to the law or teaching. He said in this situation I had to do this and that, or in this case, I had to refrain from doing this and that. The statement that I have to do this, or that I should not do this is something that is truly binding and there are no exceptions. The desire to do things outside the task is a unique human being. Everything in nature acts according to natural law, but only humans can act in accordance with the idea of law, which is in accordance with rational principles.

For Kant, assignments are standards that assess ethical behavior. You will act correctly when you follow your ethical duties and obligations, not because these duties and obligations have good consequences, and not because they can increase pleasure or pleasure, but you do so for the task. The motive of a task is to give moral value to action. Other actions that might be based on personal interests or on consideration for others. When you face your customers honestly because you want to do business with them again, you act outside of your personal interests rather than outside your duties. Acting in this way may be worthy of praise, but it has no moral value. According to deontologists, only when you act more than a task do you act ethically.

Kant developed two laws to assess ethicality. The first is the category imperative. The principle requires that a person only acts in the same way as other people who are in the same situation will act in the same way. This is a command that is obeyed and is categorical because it is unconditional and mutually exclusive. This principle must be followed even if obedience is contrary to what was chosen to do. A rational principle or moral law is being set for everyone to follow.

There are two aspects to the imperative category. First, Kant considers that the law requires an obligation, and this means that the law of ethics requires an ethical obligation. So, every ethical action that must be carried out by someone must be in accordance with the law or maxim (a concise statement containing general teachings 
or truths about human traits) ethics, that is, in terms of the law must be obeyed. Second, an act is ethically right if and only if the saying can be universally consistent. Kant uses examples of breaking promises. Assume that you want to break a promise. If you do it, then you will make your maxims followed by others. However, if other people follow this maxim, then you can be used when they break their promises to you. So, it doesn't make sense to say that everyone must keep their promises. You cannot say that you are allowed to lie to your investors about the quality of your company's financial statements, while at the same time saying that other people are not allowed to falsify their financial statements, because you might lose your investment if you accidentally depend on fake financial statements they.

Kant's second rule is a practical imperative for dealing with others. Act in the same way that you treat humanity, whether in yourself or in others, not simple, but always at the same time as the final goal. For Kant, the law has a universal application, and moral law applies to everyone without discrimination. In the same way as you as the ultimate goal, an individual with moral values, as well as other people. They too must be treated as an end in themselves, as individuals with moral values.

Kant's second rule is a practical imperative for dealing with others. Act in the same way that you treat humanity, whether in yourself or in others, not simple, but always at the same time as the final goal. For Kant, the law has a universal application, and moral law applies to everyone without discrimination. In the same way as you as the ultimate goal, an individual with moral values, as well as other people. They too must be treated as an end in themselves, as individuals with moral values. Therefore, you cannot use them in a way that ignores their moral values, just as you cannot ignore your personal moral worthiness.

\section{Virtue Ethics}

The ethics of virtue draws inspiration from the Greek philosopher Aristotle. He thinks that the purpose of life is happiness. This is not happiness in a hedonistic sense. Conversely, happiness, for Aristotle, is the activity of the soul. The purpose of life is to feel happy with a noble life, by living according to reason. Now, virtue is the character of the soul which is shown only involuntary action, that is, in actions that are freely chosen after deliberation. So, we become noble because we often do acts of virtue. However, Aristotle also felt that there was a need for ethical education so that people would know what virtuous actions were.

Aristotle thought that we could understand and identify virtues by regulating human characteristics on three things, with two extremes being evil and being good. For Aristotle, courage is a means between cowardice and rash action, simplicity is between self-satisfaction and insensitivity. Other virtues, such as pride, ambition, good emotions, friendliness, honesty, intelligence, shame, and justice can also be seen as a middle ground between two evils. Virtue is the golden mean. This is not the arithmetic mean, but the path between the extreme positions that will vary depends on the situation. It is necessary to use reason to identify the mean in each ethical situation and be better at doing this with experience, by acting noble.

Moral ethics focuses on the moral character of decision makers rather than the consequences of action (utilitarianism) or motivation from decision makers (deontology). It adopts a more comprehensive approach to understanding the ethics of human behavior. This recognizes that there are many aspects of our personality. Each of us has various characters that are developed as we become mature emotionally and ethically. Once these characters are formed, they tend to be quite stable. Our personality has many aspects and our behavior is quite consistent. Even though we all have virtues, and often the same, we show them in different degrees, even though the situation is the same.

There are two problems in ethical virtue. A key virtue in business is integrity, integrity involves being honest and respectful. For the company, this means that the

Yuli Anwar. Differences in individual demographic factors in the process accountant's ethical judgment process 
company's actions must be consistent with its principles. This is demonstrated by not sacrificing core values even when there is strong pressure to do so.

At the individual level, what are the important virtues that business people must have? Bertrand Russell thinks that Aristotle's list applies to respectable middle-aged people because they lack enthusiasm and enthusiasm and seem to base themselves on the principles of prudence and not overdo it. This list can also represent the values of middle-class public accountants. A recent effort by Libby and Thorne to identify the virtues held by public accountants resulted in a list similar to Aristotle which included honesty, sincerity, truth, reliability, determination, and trust. However, the problem with ethical virtues is that we cannot compile a long list of virtues. Furthermore, virtue may only apply to certain situations. A public accountant may need courage when telling the CFO that his accounting policy does not result in the presentation of reasonable financial statements for his company. A CEO needs directness and truth when explaining a potential downsizing to company employees and people living in communities that will be affected by factory closures.

Individuals who have the nature of relativism do not think universally because they argue that ethics is influenced by culture in each place while individuals who are idealistic have a sense of concern for others which means not thinking about themselves. This utilitarian thought must not be understood in an egoistic way and utilitarianism has the principle to produce as much happiness as possible and to distribute that happiness to as many people as possible. While deontology does not think of the consequences of actions and is not taken into consideration for something that has been done. Actions never become good because the results are good, but because they must be done. The obligation for deontology is inexorable.

\section{Ethical Judgment}

Sparks and Pan (2010) define Ethical Judgment simply as an individual's personal evaluation of the degree to which some behavior or course of action is ethical or unethical. Research conducted by Sparks et al. (2010) conduct literature research (theoretical research) to stimulate research on the psychological process behind ethical judgment.

O'Fallon and Butterfields (2005) reviewed various business ethics literature and cited 185 studies between 1996 and 2005 which contained ethical assessments as the dependent variable. To predict and explain ethical judgment, this study uses various variables, almost all of which are classified as either individual factors or organizational factors. Individual factors include demographic characteristics (ie, gender, age, occupation, education) and psychological characteristics (for example, cognitive moral development, Machiavellianism, locus of control, cognitive needs). Organizational factors include variables such as the presence or absence of codes of ethics, organizational ethics, and industry types.

Nasution and Ostermark (2012), found that social pressure affects the auditor's judgment in distance with high strength and low individualism society. Auditors who compete with undue social pressure make judgments that violate their integrity and professionalism. The paper also found that locus of control and multidimensionality of professional commitment could potentially influence auditor judgment. Amin and Dewi (2017), revealed that the auditors generally are less understood in ethic values as their guidance, thus decision making is not in accondance with the provision of Indonesian Accountant Commission, espe-cially in understanding of accountant ethic codes.

Douglas, Davidson, and Schwartz (2001) and Greenfield et al. (2008) who also claimed that more idealistic individuals rated questionable actions as more negative in the context of tax avoidance, earnings management, and audit assignments. Some previous studies said that one of the important determinants of ethical decisionmaking behavior is factors that uniquely relate to individual decision makers and 
variables that are the result of each individual's socialization and development process. These individual factors include experience, knowledge and professional commitment. Anwar, Y. et al (2018), revealed that to improve more their knowledge and to explore more the factors affecting the ethical judgement instead of the variables measured in this research. Therefore, they will be making a judgement based on the better ethical consideration

Based on the theory and explanation presented above can be used as an argument to formulate the following hypothesis:

$\mathrm{H} 1$ : There are differences in ethical judgment between age public accountants

H2: There are differences in ethical judgment between male public accountants with female public accountants.

H3: There are differences in ethical judgment between education public accountants

H4: There are differences in ethical judgment between experienced public accountants.

H5: There are differences in ethical judgment between partner and manager of public accountants.

\section{Material and Methods}

\section{Research Methods}

\section{a. Population}

According to Sugiyono (2013: 65) what is meant by population is the whole of the characteristics or units of measurement results that are the object of research. The population in this study is all Public Accountants in Indonesia registered in the 2016 Directory of Accountants and Public Accountants of Indonesia holding CPA (Certified Public Accountant) and as members of IAPI (Indonesian Institute of Certified Public Accountants). Based on the 2016 Directory of Public Accountants \& Public Accountants, the number of Public Accountant Offices (KAP) in Indonesia is 525 offices (central and branch) with 1,067 public accountants.

\section{b. Samples}

The selection of samples in this study was carried out in the following : The first stage is the selection of research sites. The research locations were chosen in five major cities in Indonesia, namely Jakarta, Bandung, Medan, Semarang and Surabaya with the following considerations. First, in the five cities there were 367 Public Accountants (KAP) (Jakarta $=258$, Bandung $=30$, Medan $=19$, Semarang $=17$, and Surabaya $=43$ ) or $69.90 \%(367 / 525)$ of all KAP in Indonesia and $83.32 \%$ of all partners registered in the 2016 Indonesian Public Accountants Directory. Second, relating to the number of partners, managers, supervisors, and senior auditors in the five cities can be considered as representing partners, managers, supervisors, and senior auditors in Indonesia. Third, the limited time and costs faced by researchers to reach all research locations.

Furthermore, sampling is done using the purposive sampling method. This method was chosen because, (1) the sample used in this study was a partner, manager, supervisor, and senior auditor status (2) as listed in Table 3.5. The number of Public Accountant Offices in Indonesia was concentrated in only a few major cities, namely in Jakarta (49.14\%), Bandung (5.71\%), Semarang (3.24\%), Surabaya (8.19\%), and Medan (3.62\%). Therefore, purposive sampling can be considered for use in this study.

Yuli Anwar. Differences in individual demographic factors in the process accountant's ethical judgment process 


\section{Data collection techniques}

The method of data collection is done through the distribution of questionnaires starting from June 2016 directly to the Public Accountant office, and shipping by using the services of Post and Giro or JNE Tiki with a postage stamp envelope. Data collection is done in a combination of the following two ways; (1) take directly to the respondent, and (2) through sending back the stamped envelopes included in sending the questionnaire with the Post and Giro or courier service. The combination of the two methods was chosen to take into account the ability of the researcher and in an effort to increase the return rate of the questionnaire.

In both methods of data collection mentioned above, the submission of questionnaires to respondents and the collection of questionnaires that have been filled out from respondents was conducted through KAP leaders or contact persons. In an effort to reduce bias in sample selection, in the introduction letter, the questionnaire was asked to KAP leaders or contact persons so that the filling out the questionnaire were partners, managers, supervisors, and senior auditors.

After a maximum of one month after sending the questionnaire to the head of the KAP or contact person, the researcher communicates by telephone to KAP leaders or contact persons who have been sent a questionnaire to ascertain whether the questionnaire they have received, and request that the completed questionnaire be sent back to the researcher.

\section{Data Analysis Techniques}

Testing the hypothesis in this study used independent sample t-test to examine the mean differences between the two independent sample groups. Testing for independent sample t-test will be carried out after data quality testing has been carried out including, (1) non-response bias, (2) outlier, (3) validity, and (4) reliability.

\section{Empirical Result and Analysis}

The output of the Independent-Samples T Test (compare means) Results in, as presented below. The testing steps for the Independent-Samples T Test type are: (a) Preceded by a variety of similarity tests (Leven's Test for Quality of Variances), then followed by a Compare Means test. (b) The similarity test of the objectives aims to test whether the same or different between the various total scores of respondents' perceptions of the ethical judgment of the age, gender, education, experience, and status the first group is the same as the total ethical judgment scores of respondents age, gender, education, experience, and status the second group. (c) The results of the equality test will be relevant to the significance value (Sig. (2-tailed)) which will be taken for the comparison test, whether in the first line (equal variances assumed) or in the second line (equal variances not assumed).

\section{Test of equality of variety (Leven's Test for Equality of Variances), a form of} statistical hypothesis:

Test of equality of variety (Leven's Test for Equality of Variances), a form of statistical hypothesis:

$$
\begin{aligned}
& H_{0}: \sigma^{2}{ }_{1}=\sigma^{2}{ }_{2} \text { or } \sigma^{2}{ }_{1}-\sigma^{2}{ }_{2}=0 \\
& H_{1}: \sigma^{2}{ }_{1} \neq \sigma^{2}{ }_{2} \text { or } \sigma^{2}{ }_{1}-\sigma^{2}{ }_{2} \neq 0
\end{aligned}
$$

$\mathrm{H}_{0}$ : The variety of respondents' total ethical judgment, age, gender, education, experience, and status the first group is same as the total ethical judgment scores of respondents in the age, gender, education, experience, and status the second group.

Yuli Anwar. Differences in individual demographic factors in the process accountant's ethical judgment process 
$\mathrm{H}_{1}$ : The variety of respondents' total ethical judgment, age, gender, education, experience, and status the first group is different from the total ethical judgment scores of respondents in the age, gender, education, experience, and status the second group.

Tests are carried out using the provisions of the real level $(\alpha)$ used at $5 \%(0.05)$. The way of decision making is:

a. Reject $\mathrm{H}_{0}$ if the significance value of significance (Sig.) Is smaller $(<)$ than the real level ( $\alpha$ ) used, and it can be concluded that the total ethical judgment scores of respondents in the age, sex, education, experience, and status the first group is different significant (significant) with a variety of respondents' total ethical judgment scores for age, gender, education, experience, and status the second group.

b. Accept $\mathrm{H}_{0}$ if the significance value of significance (Sig.) Is greater $(>)$ than the real level ( $\alpha$ ) used, and it can be satated that the total ethical judgment scores of respondents in the age, gender, education, experience, and status the first group is same (not significant) with a variety of respondents' total ethical judgment scores for age, gender, education, experience, and status the second group.

Test of homogeneity of variance test results are in accordance with Table 1, 2, 3,4 , and 5 below:

Table 1

Age and Ethical Judgment

Test of Homogeneity of Variance

\begin{tabular}{|ll|r|r|r|r|}
\hline & & \multicolumn{1}{c|}{$\begin{array}{l}\text { Levene } \\
\text { Statistic }\end{array}$} & \multicolumn{1}{c|}{ df1 } & \multicolumn{1}{c|}{ df2 } & \multicolumn{1}{c|}{ Sig. } \\
\hline Age to Ethical judgment & Based on Mean &, 019 & 1 & 299 &, 891 \\
& Based on Median &, 023 & 1 & 299 &, 879 \\
& $\begin{array}{l}\text { Based on Median and } \\
\text { with adjusted df }\end{array}$ &, 023 & 1 & 289,052 &, 879 \\
& Based on trimmed mean &, 003 & 1 & 299 &, 958 \\
\hline
\end{tabular}

Table 2

Gender and Ethical Judgment

Test of Homogeneity of Variance

\begin{tabular}{|c|c|c|c|c|c|}
\hline & & $\begin{array}{l}\text { Levene } \\
\text { Statistic }\end{array}$ & df1 & df 2 & Sig. \\
\hline \multirow{4}{*}{$\begin{array}{l}\text { Gender to Ethical } \\
\text { Judgment }\end{array}$} & Based on Mean & 1,856 & 1 & 299 & .174 \\
\hline & Based on Median & 1,182 & 1 & 299 &, 278 \\
\hline & $\begin{array}{l}\text { Based on Median and } \\
\text { with adjusted df }\end{array}$ & 1,182 & 1 & 295,208 &, 278 \\
\hline & Based on trimmed mean & 2,058 & 1 & 299 & 152 \\
\hline
\end{tabular}

Table 3

Education and Ethical Judgment

Test of Homogeneity of Variance

\begin{tabular}{|c|c|c|c|c|c|}
\hline & & $\begin{array}{l}\text { Levene } \\
\text { Statistic }\end{array}$ & df1 & df2 & Sig. \\
\hline \multirow{4}{*}{$\begin{array}{l}\text { Education to Ethical } \\
\text { Judgment }\end{array}$} & Based on Mean &, 007 & 1 & 299 &, 935 \\
\hline & Based on Median &, 064 & 1 & 299 & 800 \\
\hline & $\begin{array}{l}\text { Based on Median and } \\
\text { with adjusted df }\end{array}$ &, 064 & 1 & 291,096 & 800 \\
\hline & Based on trimmed mean &, 013 & 1 & 299 & ,908 \\
\hline
\end{tabular}

Yuli Anwar. Differences in individual demographic factors in the process accountant's ethical judgment process 
Table 4

Experience and Ethical Judgment

Test of Homogeneity of Variance

\begin{tabular}{|ll|r|r|r|r|}
\hline & & \multicolumn{1}{c|}{$\begin{array}{c}\text { Levene } \\
\text { Statistic }\end{array}$} & \multicolumn{1}{c|}{ df1 } & \multicolumn{1}{c|}{ df2 } & \multicolumn{1}{c|}{ Sig. } \\
\hline Experience to Ethical & Based on Mean &, 000 & 1 & 299 &, 993 \\
& Based on Median &, 101 & 1 & 299 &, 751 \\
& Based on Median and &, 101 & 1 & 298,577 &, 751 \\
& with adjusted df & & & & \\
& Based on trimmed mean &, 004 & 1 & 299 &, 947 \\
\hline
\end{tabular}

Table 5

Status and Ethical Judgment

Test of Homogeneity of Variance

\begin{tabular}{|ll|r|r|r|r|}
\hline & & \multicolumn{1}{|c|}{$\begin{array}{c}\text { Levene } \\
\text { Statistic }\end{array}$} & \multicolumn{1}{c|}{ df1 } & \multicolumn{1}{c|}{ df2 } & \multicolumn{1}{c|}{ Sig. } \\
\hline Status to Ethical & Based on Mean &, 158 & 1 & 299 &, 692 \\
Judgment & Based on Median &, 136 & 1 & 299 &, 712 \\
& Based on Median and &, 136 & 1 & 292,477 &, 712 \\
& with adjusted df & & & & \\
& Based on trimmed mean &, 227 & 1 & 299 &, 634 \\
\hline
\end{tabular}

Based on Table 1, 2, 3, 4, and 5 by considering the significance value of significance (Sig.) Produced is 0.891 (age), 0.174 (gender), 0.935 (education), 0.993 (experience), and 0.692 (status) and greater than the real level ( $\alpha$ ) that is used (5\%) then the decision is accepted $\mathrm{HO}$ so that it can be stated that the variety of respondents' total ethical judgment, age, sex, education, experience, and first status are the same (not significant) with the various ethical judgment scores of the age group respondents, gender, education, experience, and second status. The conclusion of homogeneity of variance testing is that there is no difference between age, gender, education, experience, and status of public accountants.

\section{Comparison Test (Compare Means Independent-Samples T Test)}

The similarity test results show that the total score of the perception of ethical judgment of the age, gender, education, experience, and status of the first group is same (not significant) with the total perception scores of the ethical judgment of respondents in the age, sex, education, experience, and status of the second group, relevant to the significance value (Sig. (2-tailed)) that must be used for the comparison test is the value in the first row or in line with the criteria (equal variances assumed), which is 0.350 (age), 0.057 (gender), 0.001 (education), 0.747 (experience), and 0.822 (status). The statistical hypothesis proposed is as follows:

$\mathrm{H}_{0}: \mu_{1}=\mu_{2}$ or $\mu_{1}-\mu_{2}=0$

$H_{1}: \mu_{1} \neq \mu_{2}$ or $\mu_{1}-\mu_{2} \neq 0$

or

$\mathrm{H}_{0}$ : The average total score of respondents' perceptions ethical judgment of the age, gender, education, experience, and status of the first group is same as the average total score based on respondents' perceptions ethical judgment of the age, gender, education, experience, and status of the second group.

$\mathrm{H}_{1}$ : The average total score of respondents' perceptions ethical judgment of the age, gender, education, experience, and status of the first group is different from the average total score based on respondents' perceptions ethical judgment of the age, gender, education, experience, and status of the second group. 
Tests are carried out using the provisions of the real level $(\alpha)$ used at $5 \%(0.05)$. The way of decision making is:

a. Reject $\mathrm{H}_{0}$ if the significance value of significance (Sig. (2-tailed)) is smaller $(<)$ than the real level ( $\alpha$ ) used, and it can be concluded that the average total score of respondents' perceptions ethical judgment of age, gender, education, experience, and status of the first group is significantly different (significant) with the average total score of respondents' perceptions ethical judgment of age, gender, education, experience, and status of second group.

b. Accept $\mathrm{H}_{0}$ if the significance value (Sig. (2-tailed)) is greater (>) than the real level (a) used, and it can be stated that the average total respondents' perceptions ethical judgment of age group, gender, the first education, experience, and status of the first group is same (not significant) with the average total score of respondents' perceptions ethical judgment of age, gender, education, experience, and status of second group.

The test of homogeneity of variance test results are in accordance with the Table 6, 7, 8, 9, and 10, below:

Table 6

Age and Ethical Judgment

\begin{tabular}{|c|c|c|c|c|c|c|c|c|c|c|}
\hline \multicolumn{11}{|c|}{ 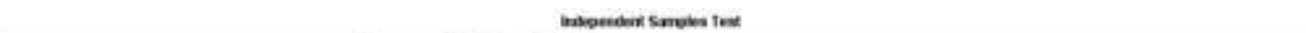 } \\
\hline & & \multicolumn{2}{|c|}{ 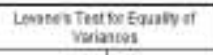 } & \multicolumn{7}{|c|}{ Hestwe Equahy st verm } \\
\hline & & \multirow[b]{2}{*}{$f$} & \multirow[b]{2}{*}{ in } & \multirow[b]{2}{*}{1} & \multirow[b]{2}{*}{ t } & \multirow[b]{2}{*}{ ouputent } & \multirow{2}{*}{ Yom } & \multirow{2}{*}{ su Emi } & \multicolumn{2}{|c|}{ 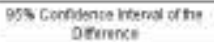 } \\
\hline & & & & & & & & & Loas & Uster \\
\hline 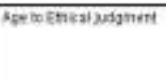 & 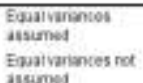 & का & 91 & & \begin{tabular}{|r|}
$>91$ \\
ist:19t
\end{tabular} & 12190 & $x$ & $\begin{array}{l}1000 \\
\sin \end{array}$ & $\begin{array}{l}-1,596 \\
-1,194\end{array}$ & M2 \\
\hline
\end{tabular}

Table 7

Gender and Ethical Judgment

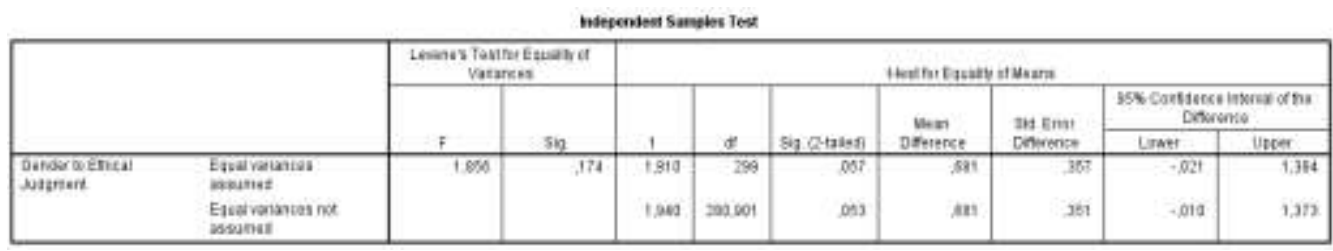

Table 8

Education and Ethical Judgment

\begin{tabular}{|c|c|c|c|c|c|c|c|c|c|c|}
\hline \multicolumn{11}{|c|}{ 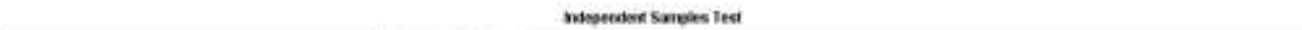 } \\
\hline & & \multicolumn{2}{|c|}{ 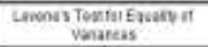 } & \multicolumn{7}{|c|}{ 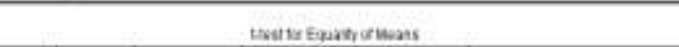 } \\
\hline & & \multirow[b]{2}{*}{ f } & \multirow[b]{2}{*}{ 39. } & \multirow[b]{2}{*}{1} & \multirow[b]{2}{*}{ a } & \multirow[b]{2}{*}{ 2in otribed } & \multirow{2}{*}{$\begin{array}{l}\text { Yean } \\
\text { Dinswacs }\end{array}$} & \multirow{2}{*}{$\begin{array}{l}\text { 8ut Enor, } \\
\text { onuafs. }\end{array}$} & \multicolumn{2}{|c|}{ 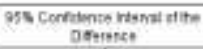 } \\
\hline & & & & & & & & & $L=1$ & Yo9ai \\
\hline $\begin{array}{l}\text { Edjexilon no retikal } \\
\text { sylmets }\end{array}$ & $\begin{array}{l}\text { Exal antirites } \\
\text { womes }\end{array}$ & IE & 995 & 3.256 & 200 & है & 7,455 & A7 & 575 & 2.334 \\
\hline & Eyaa valcotes not & & & 2698 & 69.263 & sto & $1,1,55$ & (1) & sir & $23 \times 2$ \\
\hline
\end{tabular}

Yuli Anwar. Differences in individual demographic factors in the process accountant's ethical judgment process 
Table 9

Experience and Ethical Judgment

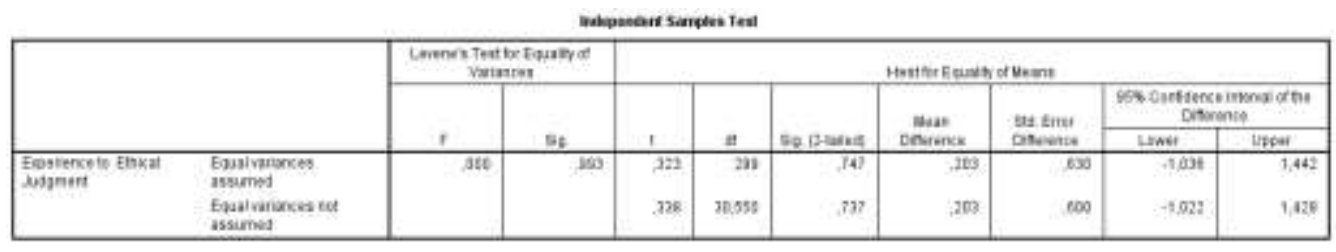

Table 10

Status and Ethical Judgment

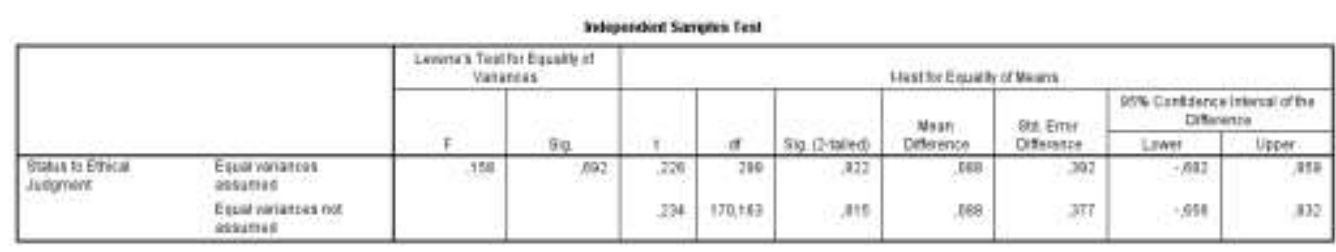

Based on Tables $6,7,8,9,10$ and considering the significance value of significance (Sig. (2-tailed)) produced at 0.350 (age), 0.057 (gender), 0.747 (experience), and 0.822 (status) and bigger than real level ( $\alpha$ ) used (5\%), then the decision accepts $\mathrm{HO}$ so that it can be stated that the average total score of respondents' perceptions of ethical judgment of age, gender, experience, and status of the first group is equal the average total score of respondents' perceptions of ethical judgment in the age, gender, experience, and status of second group. However, the value of sig. (2-tailed) produced for education is 0.001 and smaller than the real level (a) used (5\%), then the decision is accepted $\mathrm{H} 1$ so that it can be stated that the average total score of respondents' perceptions of ethical judgment of education is different (significant) with an average total score of respondents' perceptions of ethical judgment of education the second group.

Based on the results of the processing it can be concluded that age, gender, experience and status of public accountants have the same perception of ethical judgment. Decisions taken in ethical judgment when audit work is carried out by public accountants are no different what is inferred by age, gender, experience, and status of public accountants. While education of public accountants is different in terms of providing ethical judgment on the results of conclusions in carrying out audit work.

\section{Conclusions, Limitation, and Future Research}

\section{Conclusion}

Based on the results of the independent $T$ test, it can be concluded that: (a) there is no difference in ethical judgment of public accountants based on age, gender, experience, and status and (b) there are differences in ethical judgment of public accountants based on education level. These results reveal that public accountants in carrying out their duties and obligations as external auditors in private and government companies have no difference in terms of ethical judgment when deciding matters related to the audit they are undergoing due to age, gender, experience, and status .

The difference in ethical judgment of public accountants in carrying out their duties and obligations when deciding matters related to deciding audit work will be different between public accountants who have S3 and S2 education with S1 and D3. Ethical judgment carried out by those with $\mathrm{S} 3$ and $\mathrm{S} 2$ education will be more careful in deciding because if it is wrong it will have an impact on the future.

Yuli Anwar. Differences in individual demographic factors in the process accountant's ethical judgment process 


\section{Limitation and Future Research}

Limitations in sampling only in Indonesia. Future research It is better to develop the number of samples that will be used in the future by using a comparison of accountants on five continents, so that conclusions from the research results can be generalized internationally.

\section{References}

Amin, N.M., Dewi, S. (2017). Tinjauan Etika Atas Pengambilan Keputusan Auditor Berdasarkan Pendekatan Moral. Media Riset Akuntansi, Auditing \& Informasi. 1 (3): 49-62. http://dx.doi.org/10.25105/mraai.v1i3.1766.

Anwar, Y. (2016). Effect of Emotional Quality and Self Confidence toward Personal Value Including the Impact toward Understanding of Financial Accounting. International Journal of Business, Accounting and Management. 1 (1): 1-16.

Anwar, Y., Agoes, S., Amin, MN., Herusetya, A. (2018). The Effect of Understanding Codes of Ethics and Independence upon the Ethical Judgement and Personal Value as an Intervening Variable. American Journal of Theoretical and Applied Business. 4 (1): 8-14. doi: 10.11648/j.ajtab.20180401.12.

Barrainkua, I., Pike, M.E. (2017). The Influence of auditors' professionalism on ethical judgment: Differences among practitioners and postgraduated students. Spanish Accounting Review, 21 (2): 176-187.

Bertens, K. (2015). Etika Bisnis. Yogyakarta; Kanisius.

Booth, P., Schulz, A.K.D. (2004). The Impact of an Ethical Enviroment on Manager's Project Evaluation Judgment under Agency Problem Condition. Accounting, Organization and Society, 29 (5-6):473-488.

Brooks, J.L., Dunn, P. (2015). Etika Bisnis dan Profesi untuk Direktur dan Eksekutif, dan Akuntan (Edisi 5 Buku 2). Jakarta: Salemba Empat.

Douglas, P.C., Davidson, R.A., and Schwartz, B.N. (2001). The effect of organizational culture and ethical orientation on accountants' ethical judgments. Journal of Business Ethics, 34 (2): 101-121.

Greenfield, A.C., Norman, C.S., Wier, B. (2008). The effect of ethical orientation and professional commitment on earnings management behavior. Journal of Business Ethics, 83 (3): 419-434.

Griffin, R.W., Pustay, M.W. (2015). Bisnis Internasional Sebuah Perspektif Manajerial (Edisi 8). Jakarta: Salemba Empat.

IAPI. (2016). Direktori Akuntan Publik Tahun 2016. Jakarta: Salemba Empat.

Jones, J.M. (2002). Effects of year's scandals evident in honesty and ethics ratings (Gallup Poll News Service Report, December 4, 2002).

Jones, T.M. (1991). Ethical decision-making by individuals in organizations: an issuecontingent model. Academy of Management Review. 16 (3): 366-395.

Lawrence, T.A., Weber, J. (2014). Business and Society: Stakeholders, Ethics, Public Policy. New York: McGraw-Hill. 
The Accounting Journal of BINANIAGA Vol. 04, No. 01, June 2019

p-ISSN: $2527-4309$, e-ISSN: $2580-1481$

$5^{\text {th }}$ Accreditation Rating: January 14, 2019 - January 13, 2024

Nasution, D., Ostermark, R. (2012). The Impact of Social Pressures, locus of control, and professional commitment on Auditors' Judgment. Asian Review of Accounting. 20 (2), 163-178.

Nur, E.D.P., Julita., Wahyudi, D.P. (2014). Pengaruh Etika, Kompetensi, Pengalaman Auditor dan Situasi Audit Terhadap Ketepatan Pemberian Opini Audit Melalui Pertimbangan Materialitas dan Skeptisisme Profesional Auditor. Jurnal Forum Bisnis dan Kewirausahaan. 3, (3), 116-132.

O'Fallon, M.J., Kenneth D.B. (2005). A Review of the Empirical Ethical Decision-Making Literature. Journal of Business Ethics. 59 (4), 375-413.

Satava, D., Caldwell, C., Richards, L. (2006). Ethics and the auditing culture: rethinking the foundation of accounting and auditing. Journal of Business Ethics, 64 (3): 271-284.

Sparks, J.R., Pan, Y. (2010). Ethical judgments in business ethics reasearch: definition, and research agenda. Journal of Business Ethics, 91 (3): 405-418.

Sugiyono. (2013). Metode Penelitian Kuantitatif dan Kualitatif dan R\&D, Alfabeta, Bandung. 